\title{
Determinants of Farm Mechanization in Nepal
}

\author{
Arun GC ${ }^{*}$, Jun-Ho Yeo $^{2}$, Kiran Ghimire ${ }^{3}$ \\ $I^{*}$ Ministry of Agriculture, Land Management and Cooperatives, Government of Nepal, Nepal \\ Corresponding author, E-mail: gcarun88@gmail.com, ORCID: https://orcid.org/0000-0002-2548-5177 \\ ${ }^{2}$ Kyunpook National University, Department of Agricultural Economics, 41566 Korea \\ ${ }^{3}$ Ministry of Agriculture and Livestock Development, Nepal \\ E-mail: kiran.ghimire17@gmail.com,ORCID: https://orcid.org/0000-0002-2411-7233
}

\begin{tabular}{l|l}
\hline A R T I C L E I N F O & A B S T R A C T \\
\hline $\begin{array}{l}\text { Research Article } \\
\text { Received : } 21 / 07 / 2018 \\
\text { Accepted }: 07 / 11 / 2018\end{array}$ & $\begin{array}{l}\text { The paper attempts to explore the factors affecting the farm mechanization in Nepal, where } \\
\text { agriculture is the primary livelihood of most people and the mechanization is crucial for efficient } \\
\text { production and productivity. The government has also introduced a separate policy for agriculture } \\
\text { mechanization in 2014. A primary data was collected from 300 households and analysed to assess } \\
\text { and quantify the determinants of the farm mechanization. A descriptive analysis was carried out } \\
\text { for understanding the data and the results were interpreted. Similarly, the multiple regression was } \\
\text { executed to assess the factors affecting total investment in the farm machinery. The five different } \\
\text { models were specified and compared for the better results. Moreover, to have deeper insight, the } \\
\text { farm machinery was categorized into light machinery, heavy machinery and animal power. The } \\
\text { results showed that light machinery is an essential part of Nepali farming system. Likewise, the } \\
\text { presence of animal power, income per capita, per capita farm area, adaptation due to change in } \\
\text { temperature, Household size, Farm area and income are significant determinants for total } \\
\text { investment in farm mechanization. }\end{array}$ \\
$\begin{array}{l}\text { Feym } \\
\text { Mechanization } \\
\text { Investment } \\
\text { Nepal }\end{array}$ &
\end{tabular}

(c) (1) () T) This work is licensed under Creative Commons Attribution 4.0 International License

\section{Introduction}

Farm Mechanization or Agriculture mechanization (AM) is a wide field and is a multi-dimension concept (Emami et al., 2018) which generally defined as the application of implements, tools and other machinery to achieve agricultural production (Houmy et al., 2013). More precisely the Food and Agriculture Organization (FAO) has defined AM as the process of improving farm labour productivity through the application of agricultural tools, implements and machinery (FAO, 2018). Mechanization can be used at any stage of agriculture production (Emami et al., 2018). The main objective of $\mathrm{AM}$ is an efficient use of resources and it provides several social and economic benefits to farmers (ICAF, 2017). However, mechanization itself is a resource intensive option, which is also correlated with the higher level of mechanization in the developed economy as compared to developing economies. For example, FM in -the USA is 95 percent, Brazil is 75 percent, China is 57 percent and India is 40 percent (ICAF, 2017).

Adoption of AM is associated with several socioeconomic and environmental factors along with regulatory mechanisms. Very firstly, level of AM is affected by the availability of particular farm machinery (FM). Further, the adoption of the FM is affected by income, farming system, knowledge, government subsidy and other factors. The AM is driven by several factors including "agriculture labour shortage", contract farming, credit access, market penetration of implements and demand rise for food (ICAF, 2017). Moreover, the AM has also a significant impact on supply and demand for farm labour, agriculture profitability and change in the rural landscape (Schmitz and Moss, 2015)

Now, the world has started to search for the alternative of traditional mechanization in agriculture. The renewable energy backed multipurpose system for FM was found marginally more expensive than conventional fossil fuelbased FM (Mousazadeh et al., 2009).

\section{Agriculture Mechanization in Nepal}

The major sources of farm power in Nepal are animal power (36.3\%), human power $(40.5 \%)$ and the mechanical power (23\%) (Shrestha, 2012). Similarly, another study revealed that tractor users in Nepal are just 8 percent, iron plough users are 26 percent and 60 percent of intercultural operations are carried out by women (Kaur, 2017). Around 2.7 percent of farmers have their own iron animal-drawn plough, 3 percent have their own hand sprayer in the hill, 12 percent have own bullock cart in Terai and some innovative farmers have imported some combine harvesters for custom hiring (Shrestha, 2012). Although, farm size in Nepal is small, the trend of adoption of the four-wheeler tractors are increasing (Takeshima and Liu, 2018). However, it is estimated that around 85 percent of tools using by farmers in hill is handmade (Shrestha, 2012). 
Agriculture Mechanization Promotion Policy, 2071 (AMPP-2071)

The overall guiding policy of Nepalese Agriculture is National Agriculture Policy -2004 (GC and Ghimire, 2018). However, the government has introduced a separate Agriculture Mechanization Promotion Policy, 2071 in 2014 aiming to promote geography specific, women-friendly and eco-friendly mechanization, to promote public-private-cooperative partnership and to establish the institutional mechanism. It took more than 60 years to have specific agriculture mechanization policy since the start of agriculture mechanization in 1953 with the establishment of Agriculture Engineering Unit (MoALMC, 2018). The AMPP-2071 has identified key challenges for agriculture mechanization, which includes limited knowledge to farmers; land fragmentation; geographic difficulties; week rural infrastructures and power shortage; lack of appropriate policy; reliance on imported machinery and poor after services; limited structural provision for agriculture mechanization; and limited access to credit. The key provisions of the AMPP2017 are priority and facilitation on credit access, capital subsidy on purchase of agriculture machinery, identification and promotion of multipurpose machinery, separate number-plate for subsidized vehicles for agriculture purpose, human resource development, Intellectual property rights for indigenous knowledge and equipment, and promotion of public-private-cooperative partnership. The AMPP-2071 has also emphasized to promote machineries appropriate for Good Agriculture Practices.

\section{Methodology}

A household survey of 300 households was carried out in 10 sample districts out of 75 districts to represent all five development regions and three geographical regions (High Hills, Mid Hills and Terai) of Nepal in 2015. A random sample survey was carried out for data collection after districts were selected.

The Ordinary Least Square (OLS) method was applied to quantify the determinants of AM. After several rounds of execution of the OLS, a full model or unrestricted model was developed, other four restricted models were specified, and the regression was carried out. Thus, developed models were compared for a better result. The multiple regression model can be generalized as in the equation (1).

$$
\mathrm{TI}=\alpha+\beta \mathrm{X}_{\mathrm{i}}+\varepsilon
$$

Here the outcome variable is the total investment in farm machinery (TI). The investment in farm machinery has been grouped into three categories - light machineries (like a basket, plough, sickle, file, etc), heavy machinery (like the pump, tractor, thresher, etc) and animal power. Likewise, $\alpha$ is an intercept, $\beta$ is the vector of coefficients of independent variables, $X_{i}$ is the matrix of independent variables and $\varepsilon$ is the error terms.

\section{Variable Description}

Selections of the explanatory variables are always crucial for regression analysis. The explanatory power of the variables also depends on the socio-economic and geographical setting. For example, rural infrastructure could be an important determinant for developing countries; however, it would not be an issue for the developed economy. For developed countries, cost of machinery would be a single largest determinant for agriculture machinery, which might not have the same level of influence in the least developed countries. Thus, for selection of explanatory variables, the AMPP-2017 has been considered to great extent because it has identified the challenges and constraint of agriculture machination in Nepal. The description of variables has been presented in Table-1.

Table 1 Description of variables

\begin{tabular}{|c|c|c|c|c|c|}
\hline Variable & Description & $\mathrm{O}$ & $\mathrm{M}$ & SD & ER \\
\hline TI & Total Investment on AM in Ten thousand rupees & 300 & 146.39 & 689.80 & NA \\
\hline HM & Investment on Heavy Machineries (Tractor, Thresher, Pump, etc) & 300 & 0.95 & 0.22 & + \\
\hline AP & Investment on Animal Power & 300 & 0.48 & 0.50 & + \\
\hline IncPC & Per capita income & 284 & 7.18 & 10.39 & - \\
\hline IncPA & Per hector income & 296 & 59.56 & 105.10 & - \\
\hline Adult & Total number of adults in the household & 285 & 3.78 & 1.94 & + \\
\hline TemAdp & Adaptation due to temperature change; if Yes $=1$; otherwise 0 & 300 & 0.61 & 0.49 & + \\
\hline DrgAdp & Adaptation due to precipitation change; if Yes $=1$; otherwise 0 & 300 & 0.36 & 0.48 & + \\
\hline Terai & Household is in Terai region; if Yes $=1$; otherwise 0 & 300 & 0.30 & 0.46 & + \\
\hline FarmDecisions & Decision taken by head of household; if Yes $=1$; otherwise 0 & 300 & 0.83 & 0.38 & + \\
\hline FarmExp & Year of farming experience & 300 & 24.83 & 14.18 & - \\
\hline HHSize & Household size in number & 284 & 6.00 & 3.12 & $+/-$ \\
\hline AgeHoH & Age of head of household & 283 & 50.90 & 12.44 & - \\
\hline GenderHoH & Gender of head of household & 283 & 0.10 & 0.29 & - \\
\hline EducHoH & Year of schooling of head of household & 274 & 6.78 & 4.34 & + \\
\hline Internet & Whether the household has internet access; if Yes $=1$; otherwise 0 & 283 & 0.22 & 0.41 & + \\
\hline NumPlots & Number of plot that the household is owning & 296 & 1.75 & 0.57 & - \\
\hline FarmArea & Farm area in hector & 300 & 1.11 & 2.50 & + \\
\hline Tenure & Ownership of farming land; if own $=1$; otherwise 0 & 296 & 0.88 & 0.33 & + \\
\hline SellDist & Time taken to sell household produces in kilometre & 278 & 2.79 & 3.83 & - \\
\hline GetExt & Whether the household has access to extension services; if Yes $=1$; otherwise 0 & 297 & 0.73 & 0.45 & + \\
\hline Income & Total household income in ten thousand rupees & 300 & 36.01 & 52.06 & - \\
\hline PCfarmIncome & Percentage of household income coming from farming & 300 & 70.72 & 35.00 & + \\
\hline BorrowedYN & Whether the household has credit access; if Yes $=1$; otherwise 0 & 299 & 0.40 & 0.49 & + \\
\hline FarmAdultFemales & Number of female adults working in farm & 283 & 2.22 & 1.34 & - \\
\hline FarmAdultMales & Number of male adults working in farm & 286 & 1.57 & 1.04 & + \\
\hline
\end{tabular}

O: Obs, M: Mean, ER: Expected Relation, SD: Std. Dev. 


\section{Result}

\section{Types of Machinery}

For a better understanding of investment in the farm machinery, total investment was separated into three categories - Light Machinery (LM), Heavy Machinery (HM) and Animal Power(AP).The Figure-1 presents the distribution of household investment in three categories of FM. Due to higher per unit cost for the heavy machinery, the major share of investment is retained by it. The study found that $98.67 \%$ household has at least some kind of LM, which is either owned solely by the household or jointly. Similarly, 94.33 percent household owned, at least some kind of heavy machinery, either solely or jointly. And the case for animal power was found 47.67 percent.

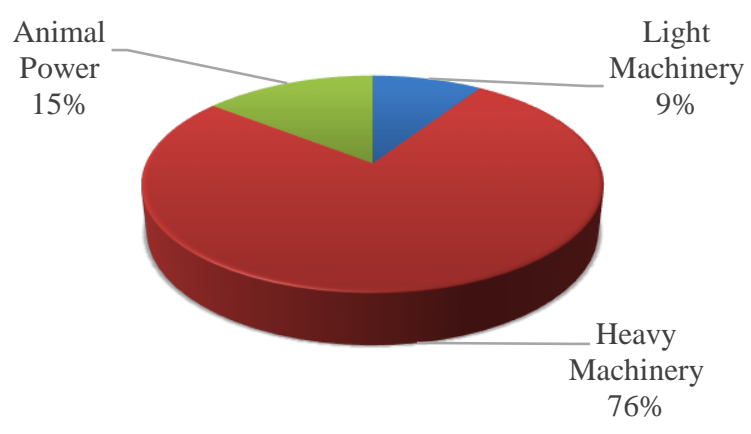

■Light Machinery $\square$ Heavy Machinery $\square$ Animal Power

Figure 1 Investment in different machinery

\section{Household Characteristics}

The proportion of households where the farming decision was taken by the head of household was found similar for adopter and non-adopter of heavy machinery and animal power, which was above 80 percent. Household size was found slightly different for adopter (6) and non-adopter (5) of HM, and almost similar was the case for AP. In case of gender, for HM, more than 85 percent head of household was reported male if they have any kind of HM, whereas, just more than 28 percent head of household was found male if they have not adopted HM. However, for AP, around 67 percent household head were male for adopter, but it was just 12 percent for nonadopter. Likewise, the average year of schooling was found 7 for both adopter and non-adopter of HM. However, the average year of schooling was found 6 for adopter and 8 for non-adopter of HM.

\section{Household Endowment}

Farming household who have HM found owing more land than those who have not. The average land holding of HM adopter farming household was found 1.15 ha, however, the average land holding was found just 0.41 for non-adopter of HM. Contrary to HM, for AP, both adopter and non-adopter farming households have just around 1 ha land. Likewise, in the case of the number of plots, it was found around 2 for both adopter and nonadopter, and for HM and AP. Similarly, for ownership, almost 90 percent adopter households have own farming land and the percent was just around 80 for non-adopter who have their own land. However, for AP, both adopter and non-adopter, around 88 percent households have their own land. In the case of total household income, average income for adopter and non-adopter of HM was found 36 and 35.6 thousand per annum. However, the average income per annum was found around 34 thousand and 38 thousand for adopter and non-adopter of AP respectively. Likewise, in the case of percentage of income coming from farming activities, it was found 71 percent, 60 percent, 70 percent and 71 percent respectively for adopter and non-adopter of HM and AP.

\section{Household Access}

Around 95 percent household have access to a telephone if they have $\mathrm{HM}$ and the percentage of household was found 71 if they do not have HM. However, access to telephone in AP adopter (94\%) and non-adopter $(92 \%)$ was almost similar. In the case of internet access, it was around 20 percent - adopter of HM (22\%), non-adopter of HM (21\%), adopter of AP (18\%) and non-adopter of AP $(25 \%)$. Likewise, access of agriculture extension service was found different in case of adopter (75\%) and non-adopter (27\%) of HM, however, it is almost same for both adopter (74\%) and non-adopter $(72 \%)$ of AP. The overall statistics on credit access is low (around 40\%). The credit access for both adopter and non-adopter of HM was found 40 percent and the credit access for adopter and non-adopter of AP was found 39 percent and 41 percent respectively.

\section{Econometric Model}

Total five models were developed and compared for the study as presented in the Table-2. The first model is the full model, also known as an unrestricted model (URM) and it contains all possible candidates of explanatory variables. The unrestricted model has 253 observations and R-square is 0.647. It means the explanatory variables in the model are explaining $64.7 \%$ variability for total investment in farm machinery. Among the 24 variables, only seven variables are found significant. Similarly, the RM1 has total observation 254 and R-square is 0.648, which means the model can explain $64.8 \%$ variation in the total investment in the farm machinery. Likewise, the RM2 has 254 observations and the R-square is 0.65 , the RM3 has total observation 254 and the R-square is 0.649, and the RM4 has total observation 264 and R-square is 0.651 . Here, the variation in total observation is due to missing values in some explanatory variables. Hence, comparing these five models, the RM4 is found superior over its alternative candidate models. Therefore, we took RM4 as the final model for our study.

$$
\mathrm{TI}=205.38+(-91.85) \mathrm{HM}+(-125.69) \mathrm{AP}+(-41.21)
$$
IncPC + (-0.77) IncPA + 150.85 TemAdp + (-37.82) HHSize + (-158.87) GenderHoH+ 91.02 Internet + (43.87) NumPlots +177.54 FarmArea +121.27 Tenure + 7.93 SellDist + 11.73 Income + (-0.15) PCfarmIncome + (-51.31) BorrowedYN + (-39.45) FarmAdultFemales 
Table 2 Model Comparison

\begin{tabular}{|c|c|c|c|c|c|}
\hline Variable & URM & RM1 & RM2 & RM3 & RM4 \\
\hline HM & -58.80 & -84.32 & -85.33 & -91.52 & -91.86 \\
\hline $\mathrm{AP}$ & $-153.71 *$ & $-137.21 *$ & $-138.27 *$ & -130.62 & $-125.69 *$ \\
\hline IncPC & $-42.56 * * *$ & $-41.43 * * *$ & $-41.37 * * *$ & -42.56 & $-41.21 * * *$ \\
\hline IncPA & $-0.86 * *$ & $-0.80 *$ & $-0.80 *$ & -0.74 & $-0.77 *$ \\
\hline Adult & -3.74 & -4.42 & & & \\
\hline TemAdp & $166.76^{*}$ & $164.30 *$ & $162.98 *$ & $140.94 *$ & $150.85^{*}$ \\
\hline DrgAdp & -61.19 & -74.82 & -73.76 & -72.34 & \\
\hline Terai & -80.31 & & & & \\
\hline FarmDecisions & 108.32 & 79.45 & 79.94 & 75.03 & \\
\hline FarmExp & -1.15 & -0.25 & -0.29 & 0.08 & \\
\hline HHSize & $-40.66 * *$ & $-37.73 * *$ & $-38.72 * *$ & -39.26 & $-37.82 * * *$ \\
\hline AgeHoH & 1.31 & & & & \\
\hline GenderHoH & -203.73 & -191.85 & -190.59 & -172.34 & -158.87 \\
\hline EducHoH & -3.18 & -3.80 & -3.74 & -2.86 & \\
\hline Internet & 105.33 & 106.04 & 105.09 & 101.32 & 91.02 \\
\hline NumPlots & -52.98 & -50.55 & -51.02 & -51.28 & -43.87 \\
\hline FarmArea & $180.13 * * *$ & $177.68 * * *$ & $177.61 * * *$ & $177.90 * * *$ & $177.54 * * *$ \\
\hline Tenure & 115.40 & 120.50 & 121.37 & 122.93 & 121.27 \\
\hline SellDist & 6.06 & 7.96 & 7.87 & 8.23 & 7.93 \\
\hline GetExt & -1.18 & 2.01 & 1.86 & -0.54 & \\
\hline Income & $12.09 * * *$ & $11.89 * * *$ & $11.87 * * *$ & $12.13 * * *$ & $11.73 * * *$ \\
\hline PCfarmIncome & -0.13 & -0.08 & -0.08 & 0.01 & -0.15 \\
\hline BorrowedYN & -32.97 & -49.55 & -50.44 & -52.21 & -51.31 \\
\hline FarmAdultFemales & -33.58 & -35.13 & -40.06 & -40.90 & -39.45 \\
\hline Constant & 123.11 & 166.03 & 166.06 & 135.62 & 205.38 \\
\hline $\mathrm{N}$ & 253 & 254 & 254 & 254 & 264 \\
\hline r2_a & 0.65 & 0.65 & 0.65 & 0.65 & 0.65 \\
\hline
\end{tabular}

\section{Discussion}

The farm mechanization is considered as the essential for modern agriculture (Rasouli et al., 2009). It is also considered as a promoting factor for higher output and to increase the profitability of farming (Ghosh, 2010). The total income is found one of the most influential determinants along with total area and household size. The role of income to the total investment in the farm machinery has further defined by per capita income and per hectare income of the household. The result suggests that each unit increment in total household income will increase investment by 11.73 . However, this figure alone cannot give the full picture. Therefore, we took another variable per capita income and per hectare income. However, surprisingly, the result showed that both variables have a negative relationship with the total investment in farm machinery. Each unit increase in per capita income will reduce the total investment by 41.21 . Likewise, each unit increase in per hectare income, the investment in farm machinery will decrease by 0.77 . These results show that though income itself is strong positive determinant neither per capita income nor per hectare income is supporting total investment in farm machinery. The result suggests that the source of income is an important factor, which we should consider. It indicates that the major chunk of total income is not coming from agriculture in general. However, if the major income is from agriculture, their landholding is not big enough to influence investment in farm machinery. Per unit increment in per capita income and per capita farm area lead to shrinking of TI by 41.21 and 0.77 respectively. Nepali farming household is largely poor and the marginal propensity to consume is the higher for the poor (Cervantes-Godoy and Dewbre, 2010), which may result on diverting of resources to consumption instead of investment. Likewise, it was found that growth in the adoption rate has comparatively limited for farm size less than 0.5 ha (Takeshima and Liu, 2018). Another important explanatory variable is household size. The number of household member has a direct influence on total saving of the household and which ultimately determine the total investment. The result suggests the negative relation of HHSize to total investment. It is indicating that a higher number of family member will decrease the total saving keeping other factors constant. Likewise, the model suggests that having heavy machinery is inversely related to total investment in farm machinery (TI), however, it is not significant. Moreover, the presence of heavy machinery is producing insignificant results in all specified models. It might suggest that the level of heavy mechanization is not significant at this level. If so, the meaning of the result is that Nepal is at the primary level of mechanization. On other hands, the presence of animal power has also an inverse relationship with TI and is significant. It means the presence of animal power reduces investment in farm machinery by 125.69 . Household size, a female as head of household, number of plots, and the percentage of income coming from the farm, credit access and number of adult 
female working in farm have produced inverse relation with TI. The increase in each number of family members, the percentage of income coming from farm and the number of adult female working in the farm decrease the TI by 37.82, 0.15 and 39.45. Likewise, having more than one plot and having credit access reduce TI by 43.87 and 51.31 respectively. However, internet access, total farm area, tenure, selling distance and total household income have a positive relationship with TI. Having internet access and having own land increase the TI by 91.02 and 121.27 respectively. Likewise, each unit increase in farm area, selling distance and income increase TI by 177.54 , 7.93 and 11.73 respectively. Moreover, it was reported that when tractors are not used for plough, animal power is likely to be used (Takeshima \& Liu, 2018)

\section{Conclusion}

Agriculture mechanization is a multi-dimensional concept, which covers the wider spectrum of agriculture from biology to sociology and ecology to economics. The case of AM in Nepal is a unique due to the higher dependency of the active population in agriculture, which generates almost one-third of GDP, small land parcel, fragmented land, resource-poor farmers, diverse agroecology and farming system. Several studies suggested that the rate of AM is growing, and the government is promoting it by enacting the separate agriculture mechanization policy in 2014. The empirical analysis of 300 households revealed that light machinery is an essential part of Nepali farming system. However, heavy machinery is still not flourished enough in Nepal. Likewise, the presence of animal power, income per capita, per capita farm area, adaptation due to change in temperature, Household size, Farm area and income are significant determinants for total investment in farm mechanization. On the basis of the research, we can recommend that land consolidation is very essential to the higher rate of adoption of AM and will further be accelerated by higher income generation from the farm. Moreover, increasing farm income is crucial to increase the total investment in farm mechanization.

\section{References}

Cervantes-Godoy D, Dewbre J. 2010. Economic Importance of Agriculture for Poverty Reduction "OECD Food, Agriculture and Fisheries Working Papers", No. 23. France: OECD Publishing. Available from: https://www.oecd.org/tad/44804637.pdf doi: $10.1787 / 5 \mathrm{kmmv} 9 \mathrm{~s} 20944-\mathrm{en}$

Emami M, Almassi M, Bokhoda H, Kalantari I. 2018. Agricultural mechanization, a key to food security in developing countries: strategy formulating for Iran. Agriculture \& Food Security , 7:24. Availabe from: https://agricultureandfoodsecurity.biomedcentral.com/article s/10.1186/s40066-018-0176-2 DOI: https://doi.org/ $10.1186 / \mathrm{s} 40066-018-0176-2$
FAO. 2018. Mechanization. Retrieved from Food and Agriculture Organization of the United Nations: Availabe from: http://www.fao.org/tc/exact/sustainable-agricultureplatform-pilot-website/energy-

management/mechanization/en/

GC A, Ghimire K. 2018. A SWOT analysis of Nepalese agricultural policy. International Journal of Agriculture, Environment and Food Science, 2(4):119-123. Availabe from: http://dergipark.gov.tr/jaefs/issue/39110/422397 DOI: $10.31015 /$ jaefs. 18020

Ghosh BK. 2010. Determinants of Farm Mechanisation in Modern Agriculture: A Case Study of Burdwan Districts of West Bengal. International Journal of Agricultural Research, 5: 1107-1115. Availabe from: https://scialert.net/ fulltext/?doi=ijar.2010.1107.1115 DOI: 10.3923/ijar.2010. 1107.1115

ICAF.2017. Farm Mechanization: National Round Table Conference. New, Delhi: Indian Council of Food and Agriculture (ICAF). Availabe from: http://icfa.org.in/assets/ doc/reports/RTC_Farm_Mechanization.pdf

Kaur A. 2017. Agricultural Mechnization in Nepal. New Delhi: International Food Policy Research Institute, South Asia Office. Availabe from: http://southasia.ifpri.info/ 2017/04/07/agricultural-mechanization-in-nepal/

MoALMC.2018. The Collection of Agriculture Related Policies. Kathmandu: Ministry of Agriculture, Land Managment and Cooperatives, Nepal.

Mousazadeh H, Keyhani A, Mobli H, Bardi U, Asmar T E. 2009. Sustainability in Agricultural Mechanization: Assessment of Combined Photovoltaic and Electric Multipurpose System for Farmers. Sustainability ,1: 10421068. Available from: https://www.mdpi.com/journal/ sustainability/special_issue/renewable-agriculture doi:10.3390/su1041042

Rasouli F, Sadighi H, Minaei S. 2009. Factors Affecting Agricultural Mechanization: A Case Study on Sunflower Seed Farms in Iran. J. Agri. Sci. Technol, 11(1): 39-48. Available from: http://jast.modares.ac.ir/article-23-8735en.html

Schmitz A, Moss CB. 2015. Mechanized Agriculture: Machine Adoption, Farm Size, and Labor Displacement. The Journal of Agrobiotechnology Managment \& Economics, 18(3): 278-296. Available from: http://www.agbioforum.org/ v18n3/v18n3a06-schmitz.htm

Shrestha S. 2012. Status of Agriculture Mechanization in Nepal. Avaliable from http://www.unapcaem.org/activities $\% 20$ files/a1112rt/np.pdf

Takeshima H, Liu Y. 2018. The Role of Plant-Breeding R\&D in Tractor Adoption among Smallholders in Asia: Insights from Nepal Terai. Working Papers id:12748, eSocialSciences. Available from: https://ideas.repec.org /p/ess/wpaper/id12748.html 